\title{
GABA Stimulates Chemotaxis and Chemokinesis of Embryonic Cortical Neurons via Calcium-Dependent Mechanisms
}

\author{
Toby N. Behar, Yong-Xin Li, Hung T. Tran, Wu Ma, Veronica Dunlap, Catherine Scott, and Jeffery L. Barker \\ Laboratory of Neurophysiology, National Institute of Neurological Disorders and Stroke, National Institutes of Health, \\ Bethesda, Maryland 20892
}

During rat cortical development, when neurons migrate from the ventricular zone to the cortical plate, GABA localizes within the target destinations of migratory neurons. At this time, cells in germinal zones and along migratory pathways express GABA receptor subunit transcripts, implying that in vivo, GABA may be a chemoattractant. We used an in vitro strategy to study putative chemotropic effects of GABA on embryonic rat cortical cells.

GABA stimulated neuronal migration in vitro at embryonic day 15 (E15). From E16 onward, two concentration ranges ( $\mathrm{fM}$ and $\mu \mathrm{M}$ ) induced motility. Femtomolar GABA primarily stimulated chemotaxis (migration along a chemical gradient), whereas micromolar GABA predominantly initiated chemokinesis (increased random movement). These effects were mimicked by structural analogs of GABA with relative specificity at

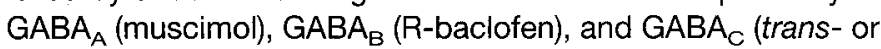
cis-4-aminocrotonic acid) receptors. Antagonists of $\mathrm{GABA}_{\mathrm{B}}$ (saclofen) and $\mathrm{GABA}_{\mathrm{C}}$ (picrotoxin) receptors partially inhibited responses to both femto- and micromolar GABA; however, only responses to femtomolar GABA were partially blocked by bicuculline, a well established antagonist of GABA at GABA $A_{A}$ receptors. Hence, chemotactic responses to femtomolar GABA seem to involve all three classes of GABA receptor proteins, whereas chemokinetic responses to micromolar GABA involve $\mathrm{GABA}_{\mathrm{B}}$ and $\mathrm{GABA}_{\mathrm{C}}$ receptor proteins.

GABA-induced motility was blocked by loading the cells with the $\mathrm{Ca}^{2+}$-chelating molecule bis(2-aminophenoxy)ethane$N, N, N^{\prime}, N^{\prime}$-tetra-acetic acid, suggesting that intracellular $\mathrm{Ca}^{2+}$ mediates GABA-induced cell movement. Optical recordings of cells loaded with $\mathrm{Ca}^{2+}$ indicator dye revealed that both femtoand micromolar GABA evoked increases in intracellular $\mathrm{Ca}^{2+}$. Thus, GABA-stimulated increases in intracellular $\mathrm{Ca}^{2+}$ may mediate both chemotactic and chemokinetic responses in embryonic cortical cells.

Key words: migration; development; cerebral cortex; GABA receptor; calcium; rat
During development of the mammalian cerebral cortex, neuronal progenitors proliferate within ventricular regions and then migrate to the cortical plate, where they differentiate and organize into layers. Neuronal migratory pathways are more complex than initially believed. Rakic (1988) proposed that neuron migration is strictly radial, occurring along fibers of radial glial cells stretching from the ventricular zone to the pial surface. However, recent studies on clonally related neurons indicate that clones derived from single progenitors exhibit a widespread tangential dispersion across the cortex, suggesting that some neurons migrate along routes that are not strictly aligned with radial glial fibers (Austin and Cepko, 1990; Walsh and Cepko, 1992). In fact, neurons in acutely prepared slice preparations of postnatal ferret cortex have been observed to move orthogonally, along nonradial pathways that are perpendicular to the axis of glial processes (O'Rourke et al., 1992, 1995). These results indicate that during corticogenesis, neurons may move in both radial and nonradial pathways. One possible mechanism that could influence nerve cell movement along these pathways involves concentration gradients of molecules released locally, which act as chemoattractants.

Potential chemoattractants should be present in appropriate locations and presumably should be released by cells. One mole-

\footnotetext{
Received Sept. 9, 1995; revised Dec. 5, 1995; accepted Dec. 7, 1995.

We thank Drs. G. D. Lange and R. Nelson for helpful discussions in the preparation of this manuscript.

Correspondence should be addressed to T. Behar, Building 36, Room 2C02, National Institutes of Health, Bethesda, MD 20892

Copyright (C) 1996 Society for Neuroscience $0270-6474 / 96 / 161808-11 \$ 05.00 / 0$
}

cule that meets these criteria is GABA, which is expressed in the marginal zone and subplate of the embryonic neocortex (Van Eden et al., 1989; Meinecke and Rakic, 1992; Schwartz and Meinecke, 1992; Ma and Barker, 1995) when neuronal migration occurs (Bayer et al., 1991; Jacobson, 1991; Meinecke and Rakic, 1992). GABA has been shown to be released from growth cones fractionated from embryonic cortical tissue (Gordon-Weeks et al., 1984; Taylor et al., 1990). GABA released in the vicinity of premigratory and/or migrating ncurons could provide chcmotropic signals that influence their motility. Since GABA can be detected hy immunocytochemistry in cells and processes that compose the target destinations of migrating cortical neurons, it would be valuable to determine whether GABA exerts chemotropic effects on neurons acutely dissociated from the developing neocortex.

Chemotropic effects have been characterized in vitro using a microchemotaxis assay (Falk et al., 1980) to quantitate cell motility in response to femtomolar to micromolar concentrations of attractants (Harvath et al. 1980; Stracke et al., 1989; Armstrong et al., 1990; Yao et al., 1990; Grant et al., 1992; Hendey et al., 1992; Rot et al., 1992; Shure et al., 1992; Geiser et al., 1993; Higashiyama et al., 1993; Reinisch et al., 1993; Behar et al., 1994a). In vitro, femtomolar to micromolar GABA induces embryonic spinal neurons to migrate (Behar et al., 1994a). We have quantified chemotropic responses of embryonic cortical neurons to GABA and found that femtomolar GABA primarily induces chemotaxis (gradient-directed migration) and pico- and micromolar GABA predominantly elicit chemokinesis (gradient-independent random 
motility). The pharmacology of these effects and their suppression by loading cells with bis(2-aminophenoxy)ethane- $N, N, N^{\prime}, N^{\prime}$ tetra-acetic acid (BAPTA-AM), which clamps intracellular $\mathrm{Ca}^{2+}$ $\left(\mathrm{Ca}_{\mathrm{c}}^{2+}\right)$ at low levels, implicale several different classes of GABA receptors coupled to signal transduction pathways involving $\mathrm{Ca}^{2+}$.

\section{MATERIALS AND METHODS}

Preparation of cells. Cortical cells from embryonic Sprague-Dawley rat pups at embryonic day 14 (E14) to E21 were analyzed. Embryonic age was determined by appearance of a vaginal plug (day 1) and measurement of crown-rump length (Schaffner et al., 1993). Dams were killed with $\mathrm{CO}_{2}$, and embryos were removed by Caesarean section. Cortices from littermates were removed, cleaned of meninges, minced, pooled, and incubated with gentle rocking at $37^{\circ} \mathrm{C}$ for $15-45 \mathrm{~min}$ in Earle's balanced salt solution (EBSS) containing $20 \mathrm{U} / \mathrm{ml}$ papain (Worthington Biochemical, Freehold, NJ), 0.005\% DNase (Boehringer Mannheim, Indianapolis, IN), $0.5 \mathrm{~mm}$ EDTA, and $1 \mathrm{mM}$ L-Cys. Tissue was triturated through a $10 \mathrm{ml}$ pipet, spun at $300 \times \mathrm{g}$ for $5 \mathrm{~min}$, and resuspended in EBSS containing $1 \mathrm{mg} / \mathrm{ml}$ bovine serum albumin (BSA; Sigma, St. Louis, $\mathrm{MO}$ ) and $1 \mathrm{mg} / \mathrm{ml}$ ovomucoid trypsin inhibitor (Sigma). The cell suspension was layered over $5 \mathrm{ml}$ of EBSS containing $10 \mathrm{mg} / \mathrm{ml}$ each of BSA and trypsin inhibitor and centrifuged at room temperature at $80 \times g$ for $7 \mathrm{~min}$. Cells were resuspended in EBSS at a concentration of $10^{6} \mathrm{cells} / \mathrm{ml}$ for the migration studies.

Cell migration. Chemotropic responses to GABA (Sigma) or GABAmimetics [muscimol (Sigma), R-baclofen (Research Biochemicals, Natick, $\mathrm{MA}$ ), and trans- or cis-4-aminocrotonic acid (TACA, CACA; Tocris Cookson, Bristol, UK)] were assessed using a microchemotaxis chamber (Neuroprobe, Cabin John, MD). Details of the microchemotaxis assay are described elsewhere (Behar et al., 1994a). Chemoattractants used in the assay were diluted in EBSS. Briefly, the lower wells of the chemotaxis chamber were each filled with $26 \mu \mathrm{l}$ of attractant. The attractants were covered with a polycarbonate filter containing randomly spaced $8 \mu \mathrm{m}$ pores (precoated with $30 \mu \mathrm{g} / \mathrm{ml}$ poly-D-lysine, molecular weight $>$ 300,$000 ;$ Sigma). The upper portion of the 48 -well chamber was placed over the filter, and each well was filled with $50 \mu \mathrm{l}$ of the cell suspension containing $10^{6}$ cells $/ \mathrm{ml}$ in EBSS (50,000 cells). Studies involving pharmacological modulation of agonist-induced migration were conducted on E17 or E18 cells. In these assays, chemoattractants (500 fM or $5 \mu \mathrm{M}$ GABA, muscimol, or baclofen; $10 \mu \mathrm{M}$ TACA or CACA, final concentrations) were mixed with potential antagonists (final concentrations, 5-50 $\mu \mathrm{M}$ 2-hydroxysaclofen, 5-50 $\mu \mathrm{M}$ picrotoxin, or 10-100 $\mu \mathrm{M}$ bicuculline methobromide). In some experiments, the calcium-chelating molecule BAPTA-AM (10 $\mu \mathrm{M}$ final concentration) was added to cells before placing them in chambers opposite $500 \mathrm{fm}$ or $5 \mu \mathrm{M}$ GABA. After an $18 \mathrm{hr}$ incubation at $37^{\circ} \mathrm{C}$ in humidified air with $5 \% \mathrm{CO}_{2}$, migrated cells on the lower side of the filter were fixed in $4 \%$ paraformaldehyde (PF) with $0.1 \%$ glutaraldehyde and stained in $0.1 \%$ cresyl violet. The membranes were mounted with the migrated cell side up onto 2 in. $\times 3$ in. glass slides, allowed to air dry, and then covered with immersion oil.

Migrated cells were counted using oil immersion $25 \times$ or $40 \times$ Zeiss Planapo objectives on a Zeiss photomicroscope (Thornwood, NY). Each chemoattractant condition was run in triplicate wells. Five to ten fields of stained cells were counted for each well, and the average number of migrated cells $/ \mathrm{mm}^{2}$ for each chemoattractant condition was calculated. In every assay, spontaneous random motility was quantitated by studying cells in buffer only. Spontaneous migration ranged between 0 and 6 cells $/ \mathrm{mm}^{2}$. Migratory responses of $\geq 50$ cell $/ \mathrm{m} / \mathrm{mm}^{2}$ were arbitrarily considered significant, since this was $\sim 10$-fold greater than spontaneous rates. Illustrations are representative plots from individual experiments performed according to the protocol outlined above. Migrations of each experimental condition were repeated in a minimum of three separate trials.

It should be noted that the number of cells that migrated in response to different GABA concentrations varied among experimental trials. However, within each experiment, migratory responses (cells $/ \mathrm{mm}^{2}$ ) to these GABA concentrations were always significant compared with control levels of spontaneous motility $[p<0.01$, ANOVA followed by Fisher's protected least significant difference (PLSD) test]. The observed variability in maximum levels of migration between experiments may be a reflection of perturbations to cells that undoubtedly occur during their dissociation and suspension and of the complexities in the physiological responses under study. Despite these inherent variabilities in the results, highly reproducible patterns in cellular motility and migration induced by GABA were observed.

Chemotaxis (the directed migration of cells toward regions of higher concentrations of a chemical attractant) was measured by placing the attractant in the bottom wells, whereas cells in the upper wells were suspended in buffer only. Under these conditions, concentration gradients of attractants can be sustained for long periods of time. Using radioimmunoassay, Armstrong et al. (1990) reported that even in the absence of cells, a lower-to-upper well concentration gradient of 2:1 was detectable $16 \mathrm{hr}$ after chamber assembly. For characterization of gradient-dependency in the chemotropic responses to GABA, E15, E16, or E18 cells were incubated in chemotaxis chambers for $18 \mathrm{hr}$ at $37^{\circ} \mathrm{C}$ and then fixed, stained, and counted as described previously. Chemotaxis was distinguished from chemokinesis (stimulation of increased random cell motility) by placing the same concentration of chemoattractant in both the upper and lower wells of the chamber, thereby eliminating a chemical gradient (GABA, $5 \times 10^{-13}$ or $5 \times 10^{-6} \mathrm{M}$ ). The number of cells migrating under these conditions was considered a measure of chemokinesis.

Characterization of migrated cells by immunocytochemistry. In some assays, migrated cells were characterized by immunolabeling with antineurofilament antibody (anti-NF; a gift from Dr. C. Gibbs, NINDS, NIH, Bethesda, MD), anti-glial fibrillary acidic protein (anti-GFAP; Sigma), anti-GABA (Incstar, Stillwater, $\mathrm{MN}$ ), or anti-glutamic acid decarboxylase (anti-GAD67; a gift from Dr. A. Lernmark, University of Washington School of Medicine, Seattle, WA) at the end of the incubation period. For immunofluorescent labeling, migrated cells were fixed for $30 \mathrm{~min}$ in $4 \%$ $\mathrm{PF}$ with $0.1 \%$ glutaraldehyde, washed, and incubated overnight at $4^{\circ} \mathrm{C}$ in mouse anti-NF (tissue culture supernatant at 1:8) or in mouse anti-GFAP (1:300). The cells were washed three times and incubated $1 \mathrm{hr}$ at $21^{\circ} \mathrm{C}$ in fluorescein isothiocyanate (FITC)-conjugated secondary antibodies [FITC goat anti-mouse IgM or FITC, rat anti-mouse IgC (1:40); Jackson Immunoresearch, West Grove, PA]. After immunolabeling, nuclei of all cells were identified by incubating them for $5 \mathrm{~min}$ in propidium iodide ( 50 $\mu \mathrm{g} / \mathrm{ml}$, Sigma), which intercalates into double-stranded DNA and fluoresces a brilliant orange using the FITC filters. Membranes were mounted with the cell side up onto slides and covered with coverslips. PBS ( $\mathrm{pH} 7.4$ ) was used for all washes, and PBS with $0.25 \%$ Triton X-100 was used as the antibody diluent.

The total number of migrated cells within a field was determined by counting the number of propidium iodide-labeled nuclei. The number of immunolabeled cells was then counted in the same field, and the percentage of cells expressing NF or GFAP was calculated. A total of 15 fields was counted in three replicate wells, and the average percentage of immunolabeled cells was determined. Labeled cells were examined on a Zeiss photomicroscope equipped with epifluorescence and appropriate filters for the visualization of FITC, using $25 \times$ and $40 \times$ Zeiss Planapo objectives. In some studies, migrated cells were analyzed for neurofilament, GABA, or GAD expression after fixation and cresyl violet staining. After the incubation in cresyl violet, migrated cells were rinsed in buffer and then incubated for $2 \mathrm{hr}$ at room temperature in primary antibody (anti-NF and tissue culture supernatant, 1:8; anti-GABA, 1:2000; antiGAD, $1: 100$ ) in PBS with $0.1 \%$ Triton X-100. The cells were washed three times and incubated in appropriate peroxidase-conjugated second antibodies (1:40, Jackson Immunoresearch) for $1 \mathrm{hr}$ at room temperature. Immunoreaction product was visualized using a diaminobenzidine substrate. Cresyl violet staining enabled the visualization of total cells, whereas the immunostaining appeared as a brown immunoreaction product that accumulated in the soma and neurites. Cells were counted under bright ficld using a $25 \times$ Zciss Planapo objective.

Immunocytochemistry of tissue sections. Timed pregnant rats at E15, $\mathrm{E} 17$, and E20 were anesthetized with sodium pentobarbital $(40 \mathrm{mg} / \mathrm{kg}$ body wcight, i.p.). The embryos were surgically removed from the mothers and were then perfused through the heart with 4\% PF in PBS, pH 7.0. The embryos were post-fixed in the same fixative for $4 \mathrm{hr}$ at $4^{\circ} \mathrm{C}$ and were then equilibrated at $4^{\circ} \mathrm{C}$ in $30 \%$ sucrose. Twelve micrometer coronal sections were cut through the middle of the forebrain using a cryostat, and the sections were mounted onto poly-L-lysine-coated slides. The immunostaining procedure was performed using indirect immunofluorescence as described previously (Behar et al., 1993). Briefly, sections were rinsed in three changes of PBS, incubated overnight at $4^{\circ} \mathrm{C}$ in polyclonal antiserum to GABA (1:300, Eugene Tech, Allendale, NY), and then rinsed three times in PBS. The sections were incubated for $45 \mathrm{~min}$ at room temperalure in rhodamine-conjugated secondary antibodies at the final dilution of 1:50 and then rinsed in PBS. Sections were overlayed with 
a mixture of glycerol and PBS (3:1), coverslips were applied, and the sections were examined under a Zeiss Axiophot photomicroscope. To identify the cytoarchitectural features of immunostained sections, coverslips were removed from some slides after fluorescence signals were photographed, and the tissue was stained with $0.2 \%$ cresyl violet.

$\left[\mathrm{Ca}^{2+}\right]$ recording. Dissociated E17 cells were placed in poly-D-lysinecoated $35 \mathrm{~mm}$ tissue culture dishes with glass coverslip bottoms (MatTek Corporation, Ashland, MA) and allowed to adhere at $37^{\circ} \mathrm{C}$ for at least 90 min. The cells were loaded with the calcium indicator dye Fura- 2 by cxposure to $4 \mu \mathrm{M}$ Fura-2 AM (Molecular Probes, Eugene, OR) in standard bath solution [(in mM) NaCl 145, HEPES $10, \mathrm{KCl} 5.4, \mathrm{CaCl}_{2} 1.8$, $\mathrm{MgCl}_{2} 0.8$; titrated to $\mathrm{pH} 7.4$ with $\mathrm{NaOH}$ and osmolarity-adjusted to 330 mosm with sucrose] for $30 \mathrm{~min}$ and then washed and maintained for 45 min for ester hydrolysis at $37^{\circ} \mathrm{C}$. Cells were perfused with $\left(37^{\circ} \mathrm{C}\right)$ standard bath solution or a solution containing GABAergic ligands at $\sim 1 \mathrm{ml} / \mathrm{min}$. Digital video imaging fluorescence microscopy was used for measuring the fluorescence of a chosen field of cells (at $40 \times$ using a Nikon inverted microscope), and images using excitation wavelengths of 340 and $380 \mathrm{~nm}$ were captured and stored. The ratio of fluorescence at the two exciting wavelengths was calculated for each pixel within a cell boundary after the experiment, and the mean ratio was recorded. Calibration of the ratio into calcium level was carried out by adding ionomycin to the dish and recording images in zero calcium medium (no calcium, $10 \mathrm{~mm}$ EGTA) and in normal medium (1.8 mM calcium). The calcium concentration is estimated from:

$$
\left[\mathrm{Ca}^{2+}\right]=K_{\mathrm{D}} F_{0} / F_{\infty} \cdot\left[R-R_{\min }\right] /\left[R_{\max }-R\right],
$$

where $K_{\mathrm{D}}$ is the Fura- $\mathrm{Ca}^{2+}$ binding constant $(\sim 220 \mathrm{nM})$ and $R$ is a ratio of fiuorescence at two wavelengths. $F_{0} / F_{\infty}$ is the ratio of fluorescence at $380 \mathrm{~nm}$ with zero calcium and $1.8 \mathrm{mM} \mathrm{Ca}^{2+}$.

In each experiment, a few cells $(\sim 3 \%)$ exhibited spontaneous fluctuations in $\mathrm{Ca}_{\mathrm{c}}^{2+}$. However, within each experiment, the incidences of agonist-evoked $\mathrm{Ca}_{\mathrm{c}}^{2+}$ signals were always significant compared with spontaneous events $(p<0.01$, ANOVA followed by Fisher's PLSD test and Scheffe's $S$ test).

\section{RESULTS}

\section{GABAergic neurons are widely distributed in the embryonic neocortex}

At E15, GABA-immunoreactive (G-IR) cell bodies and processes horizontally arrayed with respect to the pia were clearly evident in the primordial plexiform layer, which becomes layer 1; however, the neuroepithelium was unlabeled (Fig. 1). At E15, GABA expression by Cajal-Retzius cells in the rat, which compose layer 1, has been reported recently (Imamoto et al., 1994). By E17, G-IR neurons had become widely distributed throughout the cerebral wall. Most immunoreactive cells were concentrated in the formative layer 1 , the cortical subplate, the lower part of the intermediate zone, and the upper subventricular zone. Within the subventricular zone, GABA immunoreactivity was particularly prominent in cells and processes running parallel to the ventricular surface. At E20, the neuroepithelium had become thinner, whereas the cortical plate and subplate had dramatically increased in relative thickness. A large number of G-IR cells, many with processes now running perpendicular to the ventricular surface, was located within the cortical plate, subplate, and lamina I, whereas the number of G-IR cells in the subventricular and lower intermediate zone had decreased. Abundant immunolabeled processes and a few immunopositive cells were evident in the neuroepithelium and subventricular zone. These results are consistent with previous immunocytochemical studies on the distribution of G-IR cells and processes in the embryonic rat cortex (Lauder et al., 1986; Van Eden et al., 1989; Cobas et al., 1991).

\section{Neuronal migration induced by GABA in vitro is age- and dose-dependent}

Cells derived from E14 cortices did not migrate in response to any concentration of GABA $\left(10^{-15}\right.$ to $\left.10^{-5} \mathrm{M}\right)$. However, at E15 both
GABA and the GABAmimetics induced cell motility at significant levels above spontaneous rates. Immunolabeling of the migrated cells revealed that $95 \pm 3.0 \%$ expressed neurofilament protein and, hence, were considered neurons. By E18, $\sim 5 \%$ of the responding cells expressed GFAP. The total number of responding cells ranged between 1.1 and $18 \%$ of the initial starting population per well $(50,000$ cells $)$.

At E15, three discrete concentration ranges of GABA evoked cellular migration, two of which were considered significant $(>50$ cells $/ \mathrm{mm}^{2}$; Fig. 2). At this age, both picomolar (50 pM to $5 \mathrm{nM}$ ) and micromolar $(500 \mathrm{nM}$ to $5 \mu \mathrm{M})$ concentrations of GABA consistently induced significant migration. A detectable but variable small number of cells also responded to femtomolar GABA (5-500 fM). Significant levels of migration at picomolar GABA concentrations were only observed at E15. From E16 onward, only two GABA concentration ranges ( $\mathrm{f} M$ and $\mu \mathrm{M}$ ) evoked significant motility (Fig. 2). The number of cells responding to femtomolar levels of GABA increased at E16 such that at this age, the low concentration range $(5-500 \mathrm{fM})$ stimulated more cells to migrate than the high concentration range (500 nM to $5 \mu \mathrm{M})$. Thereafter, both low (5-500 fM) and high ( $50 \mathrm{nM}$ to $5 \mu \mathrm{M})$ ranges of $\mathrm{G} \Lambda \mathrm{B} \Lambda$ stimulated similar numbers of cells to migrate (Fig. 2).

To confirm the specificity of the chemotropic effects, E19 cells were placed in wells opposite $500 \mathrm{fm}$ or $5 \mu \mathrm{M}$ GABA that had been preabsorbed with specific anti-GABA antiserum (1/100) before being placed in the bottom wells of the chamber. Preabsorbtion of GABA with the specific antibody blocked the migration induced at each concentration ( 92 and $74 \%$, respectively), demonstrating the specificity of the GABA motility signals (data not shown).

In some studies, responding cells that adhered to the underside of the membrane after migration were immunolabeled with antiGABA antisera. Immunolabeling demonstrated that $13.1 \pm 0.7 \%$ of the initial E17 starting population was G-IR. However, $78 \pm$ $3.6 \%$ of the cells responding to micromolar GABA were G-IR, whereas only $11.5 \pm 6.6 \%$ of the cells stimulated by femtomolar GABA were G-IR. Thus, the population that migrated in response to micromolar GABA was enriched in GABAergic cells. To determine whether these G-IR cells were capable of synthesizing GABA, they were immunostained with antibody directed against the $67 \mathrm{kDa}$ form of $\mathrm{GAD}$, the enzyme that synthesizes GABA from glutamate and is expressed by embryonic neurons (Behar et al., 1993, 1994b). Of the cells migrating at micromolar $\mathrm{GABA}, 67.3 \pm 19.5 \%$ were $\mathrm{GAD}^{+}$, suggesting that most if not all of the micromolar-migrated population were capable of synthesizing the molecule.

\section{Femtomolar GABA primarily induces chemotaxis, and micromolar GABA predominantly stimulates chemokinesis}

We characterized the migratory responses in terms of directed movement (chemotaxis) and random motility (chemokinesis) on cells isolated from E15, E16, and E18 cortices. At each of these ages, femtomolar levels of GABA induced significantly more gradient-dependent chemotaxis than gradient-independent chemokinesis (Fig. 3). In contrast, the higher GABA concentrations (500 $\mathrm{pM}$ at $\mathrm{E} 15$ and $5 \mu \mathrm{M}$ at E15-E18) were predominantly chemokinetic (Fig. 3).

\section{GABAmimetics at $\mathrm{GABA}_{A}$ and $\mathrm{GABA}_{\mathrm{B}}$ receptors stimulate cell migration and motility}

We examined the structure activity requirements for the chemotropic effects of GABA by comparing migratory responses of E18 cells to GABA and two GABAmimetics. Agonists at both 


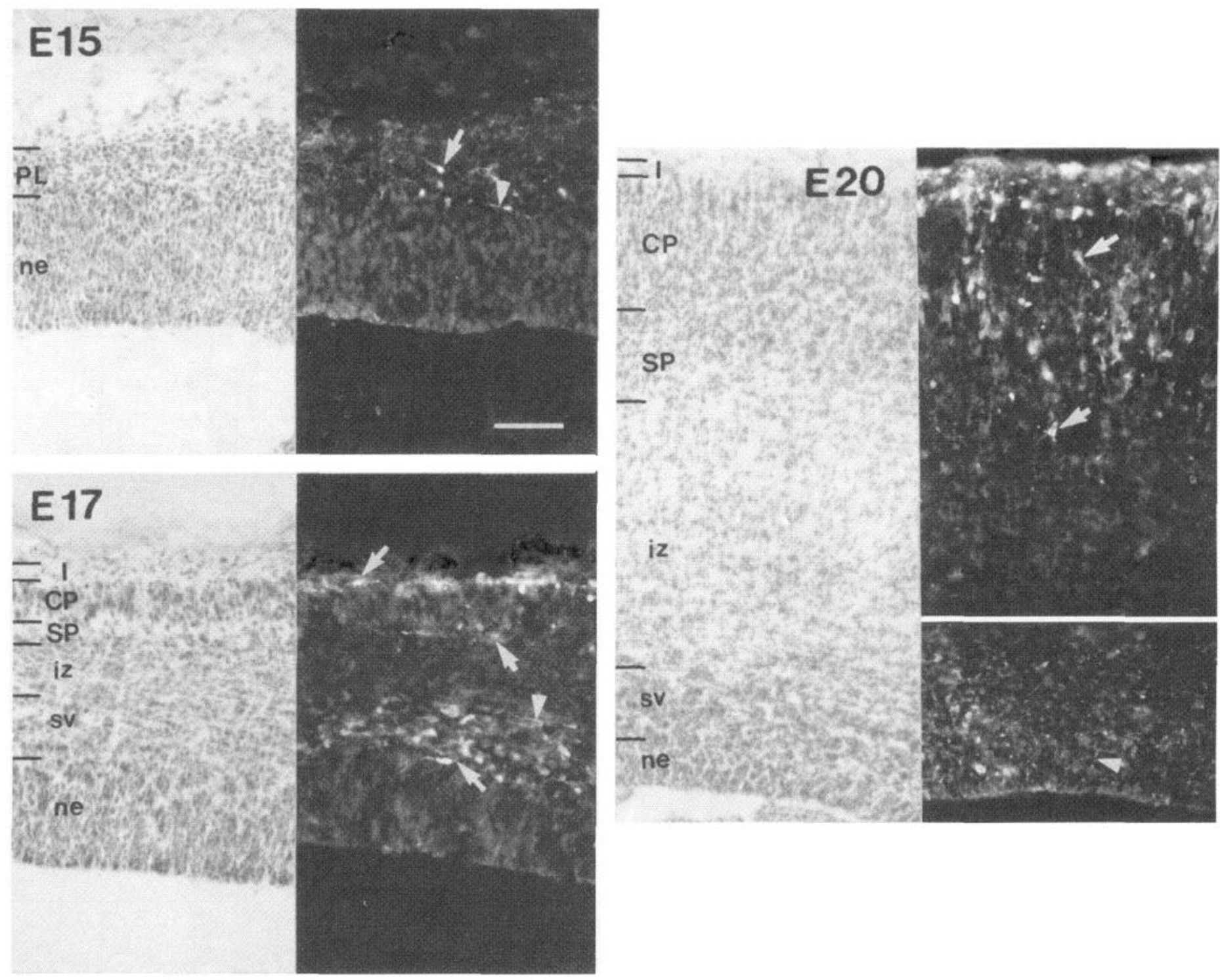

Figure 1. Developmental expression of GABA immunoreactivity in the neocortex of embryonic rats. Photomicrographs of coronal sections through the dorsomedial region of the neocortex of $E 15, E 17$, and $E 20$ embryos showing age-dependent expression of GABA immunoreactivity. A pair of adjacent sections stained for GABA immunoreactivity (right) and for cresyl violet (left) is presented in each panel. At E15, a few immunofluorescent cell bodies (arrows) and processes (arrowheads) scatter in the primordial plexiform layer (PL). By E17, immunolabeled cells and many processes running parallel to the ventricular surface are concentrated within three distinct layers: the formative lamina $I(I)$, the outer part of the subcortical plate $(S P)$, and the lower intermediate $(i z) /$ subventricular zone. At E20, G-IR cells in the lower intermediate/subventricular zone are dramatically reduced, whereas abundant immunoreactive cells and many processes running perpendicular to the ventricular surface are seen in the lamina $\mathrm{I}$, the cortical plate $(C P)$ and the subcortical plate $(S P)$. Scale bar, $50 \mu \mathrm{m}$.

$\mathrm{GABA}_{\mathrm{A}}$ (muscimol) and $\mathrm{GABA}_{\mathrm{B}}$ (R-baclofen) receptors in well differentiated CNS tissues (Sivilotti and Nistri, 1991; Bowery, 1993) mimicked the chemotropic actions of GABA (Fig. 4). The effective concentrations of the GABAmimetics closely paralleled the effective concentrations of GABA. Two concentration ranges of each agonist $(50-500 \mathrm{fm}$ and $50 \mathrm{~nm}$ to $50 \mu \mathrm{M})$ stimulated significant migration (Fig. 4). Since both muscimol and R-baclofen mimicked the effects of GABA, we attempted to inhibit GABA-induced migration using antagonists at different GABA receptors (Sivilotti and Nistri, 1991).

In competition assays, $5 \mu \mathrm{M}$ 2-hydroxysaclofen, an antagonist of GABA at well differentiated $\mathrm{GABA}_{\mathrm{B}}$ receptors in adults (Kerr and Ong, 1992; Bowery, 1993), reduced the number of cells migrating to $500 \mathrm{fm}$ and $5 \mu \mathrm{M}$ GABA by 67 and $84 \%$, respectively (Fig. 5). Similarly, $5 \mu \mathrm{M}$ picrotoxin, an antagonist of GABA at
$\mathrm{GABA}_{\mathrm{A}}$ and $\mathrm{GABA}_{\mathrm{C}}$ receptors, also blocked motility responses to both $500 \mathrm{fm}$ and $5 \mu \mathrm{M}$ GABA by 70 and $33 \%$, respectively. In contrast, $10 \mu \mathrm{M}$ bicuculline, an antagonist of GABA at $\mathrm{GABA}_{\mathrm{A}}$ (but not $\mathrm{GABA}_{\mathrm{B}}$ or $\mathrm{GABA}_{\mathrm{C}}$ ) receptors, reduced migration to 500 fM GABA (by only $44 \%$ ). Migration to $5 \mu \mathrm{M}$ GABA was either unaffected in the presence of $10-100 \mu \mathrm{M}$ bicuculline or even increased slightly (Fig. 5). These latter results indicate that chemokinetic responses to $5 \mu \mathrm{M}$ GABA are completely resistant to bicuculline, suggesting that they do not involve $\mathrm{GABA}_{\mathrm{A}}$ receptors. The antagonists alone did not stimulate motility (data not shown).

\section{$\mathrm{GABA}_{\mathrm{C}}$ receptor agonists also stimulate motility}

Recent pharmacological and molecular biological experiments have revealed a third class of GABA receptors, the $\mathrm{GABA}_{C}$ receptors, which have been initially characterized as coupled to 

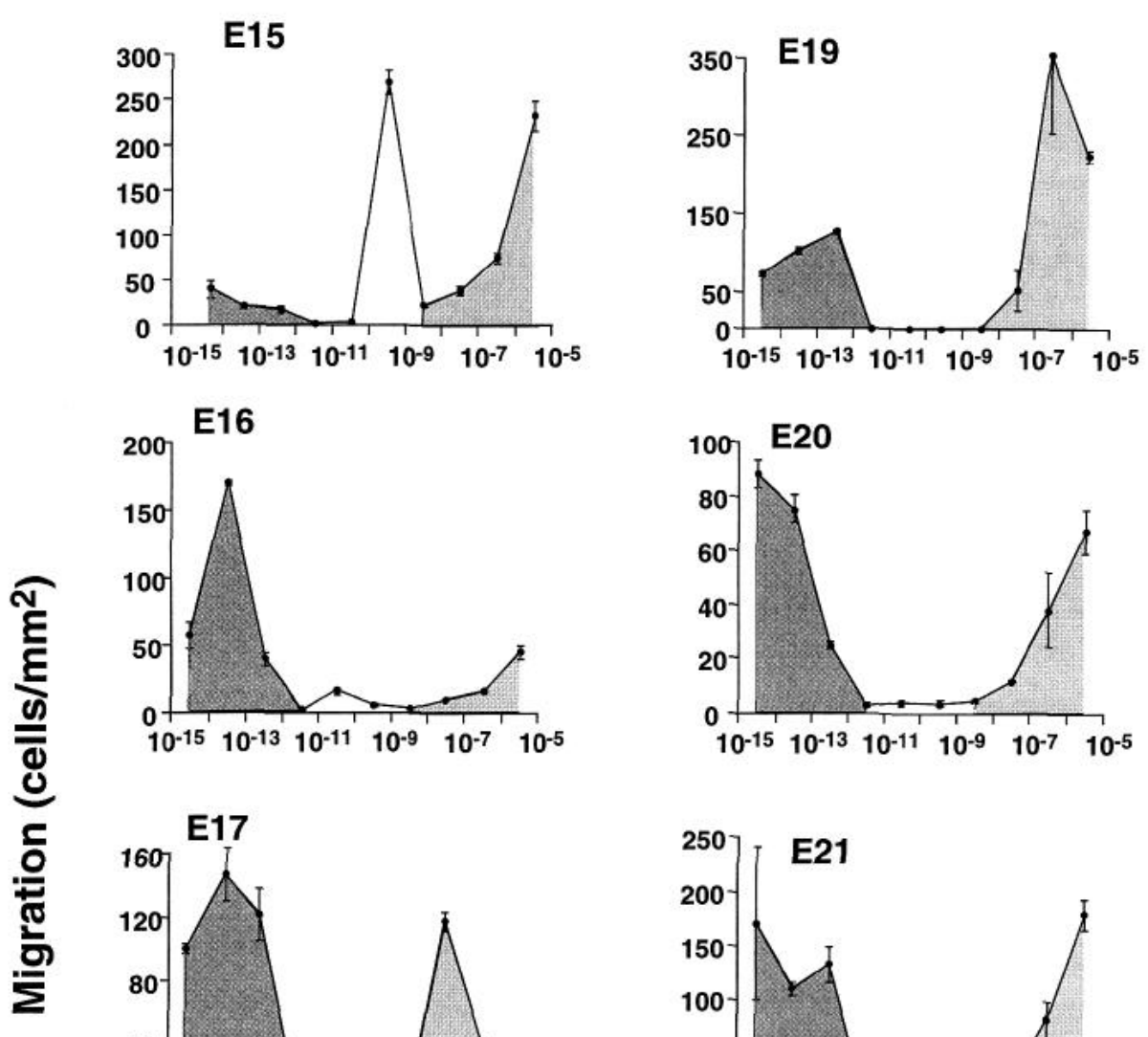

Figure 2. The migratory responses induced by GABA exhibit complex and distinctive concentration dependencies. Plots are representative individual experiments. At E15, cells migrate over three distinctive ranges of [GABA]. Micro- and picomolar concentrations induce the greatest number of cells to migrate; a small number of cells also responds to femtomolar GABA. By E16, responses to femtomolar GABA increase, whereas responses to picomolar GABA decline to insignificance. From E17 to E21, two [GABA] ranges ( $\mathrm{fM}$ and $\mu \mathrm{M}$ ) induce maximum migratory/motility responses. Error bars show SEM. Darker shading, $5 \mathrm{fm}$ to $5 \mathrm{pm}$ GABA; no shading, 50 $\mathrm{pM}$ to $5 \mathrm{nM}$ GABA; lighter shading, $5 \mathrm{nM}$ to $5 \mu \mathrm{M}$ GABA.
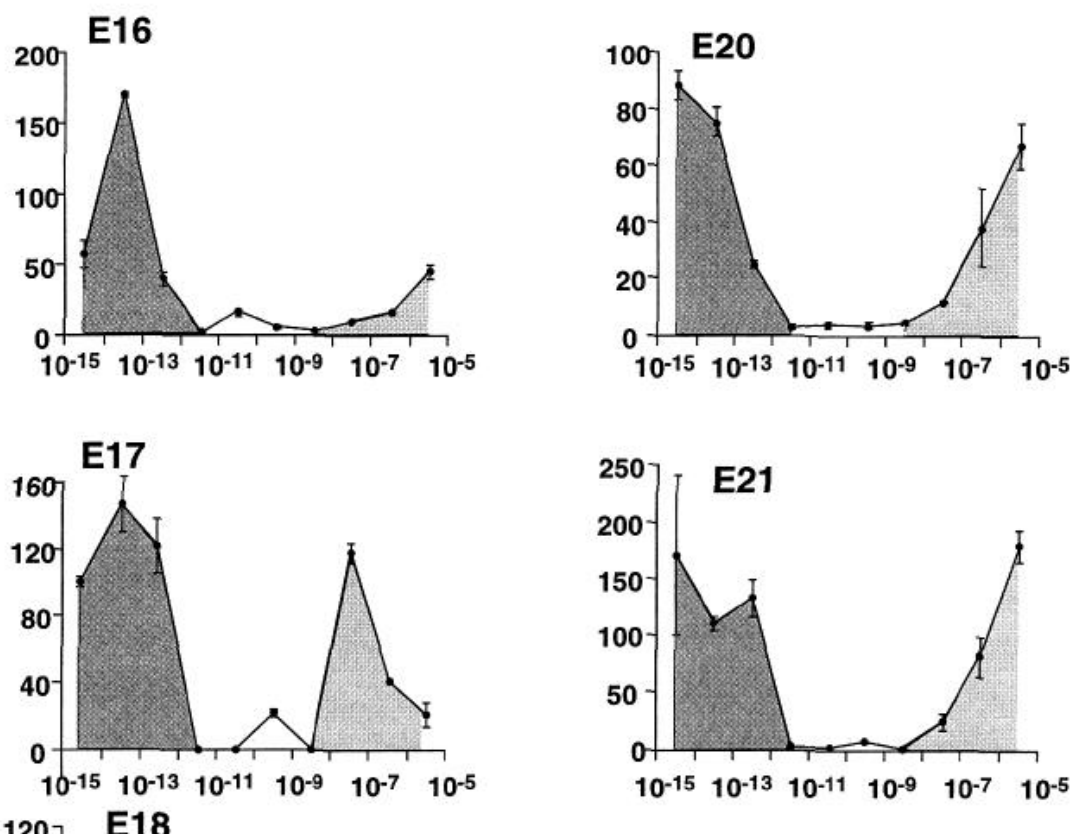

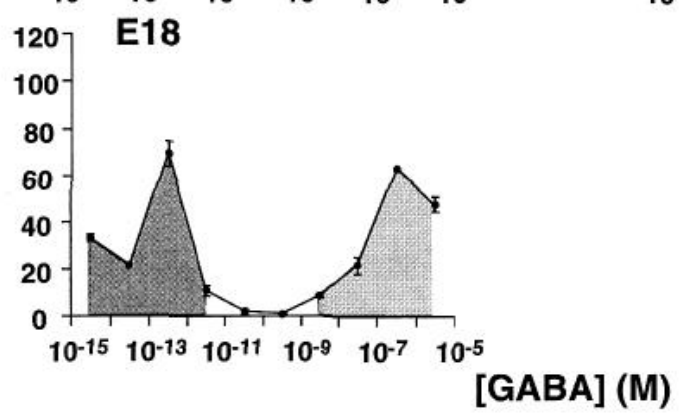

bicuculline-insensitive, picrotoxin-sensitive $\mathrm{Cl}^{-}$channels (Shimada et al., 1992; Feigenspan et al., 1993; Qian and Dowling, 1993; Jackel et al., 1994; Lukasiewicz et al., 1994). Since chemokinetic responses to micromolar GABA were entirely bicucullineresistant but were partly picrotoxin-sensitive, we studied the effects of $\mathrm{GABA}_{C}$ receptor ligands CACA and TACA (Shimada et al., 1992; Feigenspan et al., 1993; Qian and Dowling, 1993; Lukasiewicz et al., 1994) on cellular migration. Micromolar concentrations of CACA and TACA $(1-100 \mu \mathrm{M})$ stimulated maximal migratory responses in cortical cells; the optimal concentrations were $10 \mu \mathrm{M}$ for CACA and $1 \mu \mathrm{M}$ for TACA (Fig. $6 A$ ). The level of migratory responses to the $\mathrm{GABA}_{\mathrm{C}}$ receptor ligands was at least $50 \%$ of that induced by $5 \mu \mathrm{M}$ GABA, suggesting that the chemokinetic effects of GABA are mediated via $\mathrm{GABA}_{\mathrm{C}}$ receptors in a sizable subpopulation of cells. Characterization of the migratory response of E17 cells to CACA and TACA indicated that the ligands predominantly stimulate chemokinesis, rather than chemotaxis (data not shown). Picomolar to femtomolar concentrations of TACA also directed migration, but femtomolar to picomolar CACA failed to stimulate cell movement (Fig. 6A).

Motility induced by micromolar levels of TACA and CACA was blocked significantly by picrotoxin ( 74 and $95 \%$ inhibition, respectively; Fig. $6 B$ ), but not at all by either bicuculline (Fig. $6 B$ ) or saclofen $(50 \mu \mathrm{M}$; data not shown), suggesting that the picrotoxinsensitive, bicuculline-insensitive motility responses to GABA are most likely mediated via $G A B A_{C}$ receptor proteins. Interestingly, motility responses to micromolar TACA and CACA were potentiated in the presence of bicuculline (Fig. $6 B$ ), suggesting that $\mathrm{GABA}_{\mathrm{A}}$ receptor activation may actually retard or arrest chemokinesis in a subpopulation of cells. Whereas picrotoxin and saclofen each partially inhibited chemokinesis to GABA (Figs. 5, $6 C$ ), significant levels of motility were completely attenuated in the combined presence of the two antagonists (Fig. $6 \mathrm{C}$ ). Taken together, these results indicate that the chemokinetic effects of GABA involve both $\mathrm{GABA}_{\mathrm{B}}$ and $\mathrm{GABA}_{\mathrm{C}}$ receptor proteins. Migration to femtomolar TACA was partially inhibited by both of 


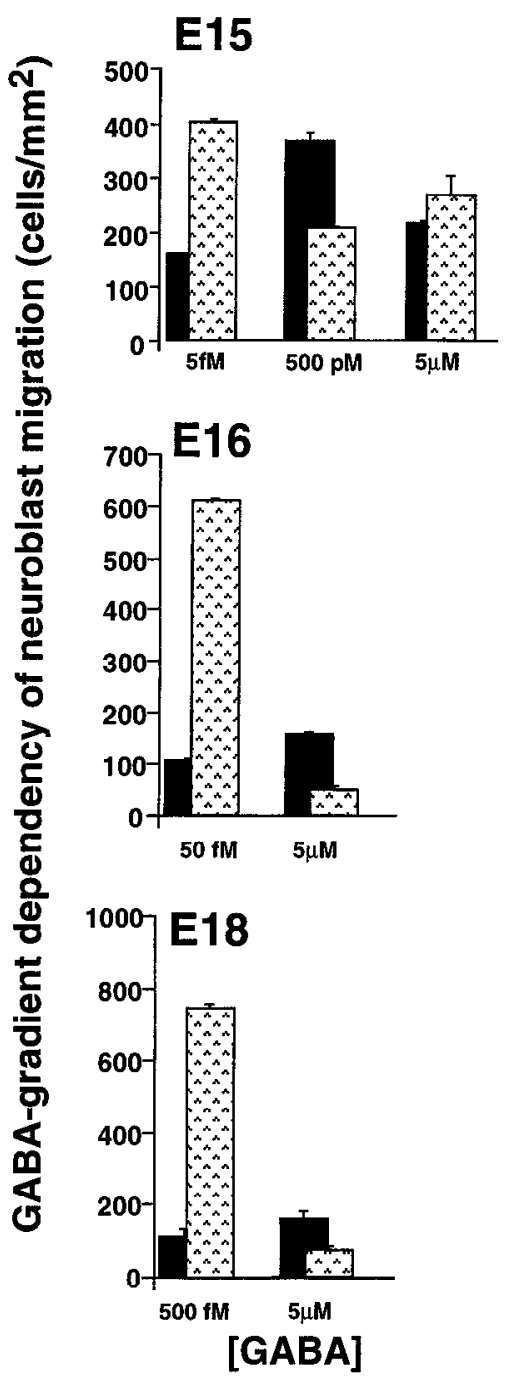

Figure 3. GABA induces chemotaxis and chemokinesis. Chemotaxis (textured burs, directed migration) was distinguished from chemokinesis (bluck bars, random motility) by placing the same concentration of chemoattractant in both the upper and lower wells of the chamber, thereby eliminating a gradient of GABA across the membrane. The number of cells migrating without a gradient was considered a measure of chemokinesis. Cells exhibit predominantly chemotactic (gradient-dependent) responses to femtomolar GABA; maximum migratory responses occur in the presence of a gradient. Both picomolar $\left(5 \times 10^{-10} \mathrm{M}\right)$ and micromolar $\left(5 \times 10^{-6} \mathrm{M}\right)$ concentrations of GABA stimulate predominantly chemokinetic responses in cells. The same or a greater number of cells migrate in the absence of a gradient as in the presence of one.

the $\mathrm{GABA}_{\mathrm{A}}$ receptor antagonists bicuculline and picrotoxin (40 and $60 \%$ respectively; Fig. $6 B$ ), suggesting that femtomolar TACA may stimulate migration via $\mathrm{GABA}_{\mathrm{A}}$ receptor proteins (Lukasiewicz et al., 1994).

Since migration and motility are believed to involve $\mathrm{Ca}^{2+}$. dependent mechanisms (Hinrichsen, 1993), we manipulated intracellular $\mathrm{Ca}^{2+}$ by loading cells with BAPTA-AM, which clamps cells at low nanomolar levels of cytosolic $\mathrm{Ca}^{2+}$. BAPTA-loaded cells did not migrate to GABA (Fig. 7), indicating that cytosolic $\mathrm{Ca}^{2+}$ elevation is involved in GABA-induced motility.

\section{Both femto- and micromolar GABA stimulate} intracellular $\mathrm{Ca}^{2+}$ increases in embryonic cortical cells

To determine whether GABA modulates the $\mathrm{Ca}_{\mathrm{c}}^{2+}$ concentration in the starting population of cells, we used digital videomicroscopy to record changes in $\mathrm{Ca}_{\mathrm{c}}^{2+}$ levels in E17 cortical cells loaded with $\mathrm{Ca}^{2+}$ indicator dye and exposed to GABA. Acutely adhered cells were recorded before, during, and after sequential applications of $500 \mathrm{fm}$ and $10 \mu \mathrm{M}$ GABA. We found that $\sim 50 \%$ of the cells recorded in five separate trials responded to one and/or the other concentration of GABA. Three classes of responding cells were observed. Most of the responsive cells $(31.2 \pm 6.2 \%)$ responded only to micromolar GABA, exhibiting a transient three- to fivefold increase in $\mathrm{Ca}_{\mathrm{c}}^{2+}$ (Fig. $8 C$ ). Few cells $(7.5 \pm 0.8 \%$ ) responded to only femtomolar GABA, which at the peak of response evoked a two- to fourfold increase in $\mathrm{Ca}_{c}^{2+}$ compared with the resting level (Fig. $8 B$ ). Another population of cells $(11.8 \pm 1.4 \%)$ responded to both femto- and micromolar GABA (Fig. $8 A$ ). Two patterns of responses to femtomolar GABA were observed. Some cells showed relatively rapid, intense, and transient rises in $\mathrm{Ca}^{2+}$ immediately after exposure to femtomolar GABA, whereas others demonstrated delayed (2-3 min) and sustained modest $\mathrm{Ca}_{\mathrm{c}}^{2+}$ signals that lasted several minutes but also extinguished during the exposure period (Fig. $8 A$ ).

In a second set of studies, 504 E17 cells were recorded in seven separate experiments after sequential exposure to $10 \mu \mathrm{M}$ R-baclofen and $10 \mu \mathrm{M}$ CACA, to determine whether individual cells respond to both ligands. Of these, $9.3 \pm 1.7 \%$ increased $\mathrm{Ca}_{\mathrm{c}}^{2+}$ only in response to baclofen (Fig. 9C). Typically, two- to fourfold increases in $\mathrm{Ca}_{c}^{2+}$ induced by baclofen were delayed 2-3 min after ligand exposure, suggesting that second-messenger-mediated signaling mechanisms may be involved in the responses. Some cells $(12.6 \pm 1.9 \%)$ responded only to CACA (Fig. $9 A$ ), whereas a subpopulation $(8.3 \pm$ $1.3 \%$ ) responded to both the $\mathrm{GABA}_{\mathrm{B}}$ and the $\mathrm{GABA}_{\mathrm{C}}$ receptor agonists (Fig. $9 B$ ). $\mathrm{Ca}_{c}^{2+}$ signals evoked by baclofen were complex and varied. In some cells, initial $\mathrm{Ca}_{\mathrm{c}}^{2+}$ transients elicited during baclofen exposure were followed by spontaneous elevations in $\mathrm{Ca}_{\mathrm{c}}^{2+}$ during the subsequent wash and blunted $\mathrm{Ca}_{c}^{2+}$ signals in a second exposure (Fig. 9B). Other cells only demonstrated increased $\mathrm{Ca}_{\mathrm{c}}^{2+}$ during the first application of the ligand (Fig. 9C). Notably, the relative number of cells responding to either micromolar CACA and/or micromolar baclofen combined $(30.2 \%)$ was similar to the percentage of total cells that exhibited elevations of $\mathrm{Ca}_{\mathrm{c}}^{2+}$ in response to micromolar GABA $(43.0 \%)$.

\section{DISCUSSION}

\section{GABAergic cells and fibers are present in the embryonic rat cortex when cells migrate to GABA in vitro}

The earliest GABAergic elements in the rat neocortex detectable by immunocytochemistry consist of scattered cells and processes within the primordial plexiform layer at E14 (Van Eden et al., 1989; Cobas et al., 1991). We found no evidence of migration or motility in vitro using dissociates of E14 cortex; however, at least two, and possibly three, populations moved in response to GABA at E15. These cells may correspond to neurons migrating in vivo toward GABAergic neurons in the primordial plexiform layer (Fig. 1). At E17, neurons destined for the cortical plate migrate away from the ventricular and subventricular zones and begin to laminate (Jacobson, 1991). At this age, we found GABAergic cells and fibers parallel to the subventricular and marginal zones, as well as a scattering of elements between the subplate and emerging cortical plate border (Fig. 1). Thus, GABA could provide postmitotic neurons within the proliferative zones with a source of chemotropic signals. By E20, GABA immunoreactivity is concentrated in cells and processes at the target destinations for migratory neurons, suggesting that at later embry- 
Figure 4. Agonists at both $\mathrm{GABA}_{\mathrm{A}}$ (Muscimol) and $\mathrm{GABA}_{\mathrm{B}}$ (R-baclofen) receptors mimic the chemoattractant effects of $G A B A$. Micromolar and femtomolar concentrations of GABA (filled circles), muscimol (open triangles), and $\mathrm{R}$-baclofen (quartered squares) stimulate maximum migratory responses in E18 cells.

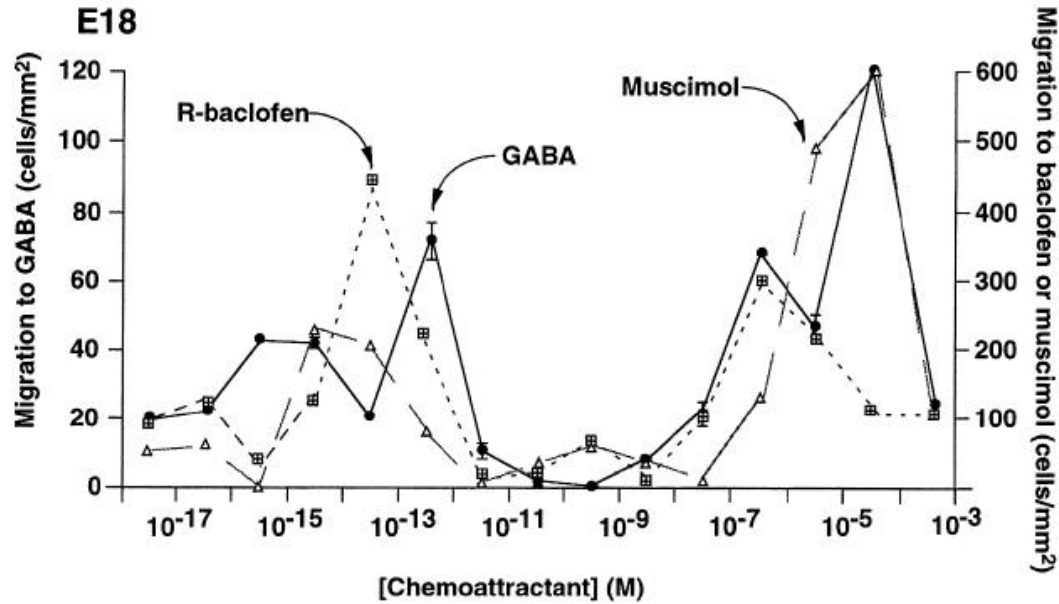

transduction pathways, resulting in embryonic cortical cell movement.

\section{Multiple GABA receptor classes mediate migration and motility}

GABA is a fast-acting neurotransmitter in the mature CNS, mediating signals usually considered to be inhibitory (Sivilotti and Nistri, 1991). In mature neurons, $\mathrm{GABA}_{\mathrm{A}}$ receptor subunit proteins form $\mathrm{Cl}^{-}$channels activated by muscimol, competitively inhibited by bicuculline, and noncompetitively inhibited by picrotoxin (Sivilotti and Nistri, 1991). $\mathrm{GABA}_{\mathrm{B}}$ receptors activate $\mathrm{K}^{+}$ and modulate voltage-dependent $\mathrm{Ca}^{2+}$ channels. $\mathrm{GABA}_{\mathrm{B}}$ receptors are bicuculline- and picrotoxin-insensitive, activated by baclofen, and antagonized by 2-hydroxysaclofen (Sivilotti and Nistri, 1991; Kerr and Ong, 1992; Bowery, 1993). GABA B $_{\text {receptors }}$ couple to G-proteins and activate intracellular second-messenger pathways. $\mathrm{GABA}_{C}$ receptors are picrotoxin-sensitive, are not blocked by bicuculline or saclofen, and fail to be activated by baclofen (Qian and Dowling, 1993). Conformationally restricted analogs of GABA, such as TACA or CACA, activate $\mathrm{GABA}_{\mathrm{C}}$ receptor-coupled $\mathrm{Cl}^{-}$channels (Feigenspan et al., 1993; Qian and Dowling, 1993; Lukasiewicz et al., 1994).

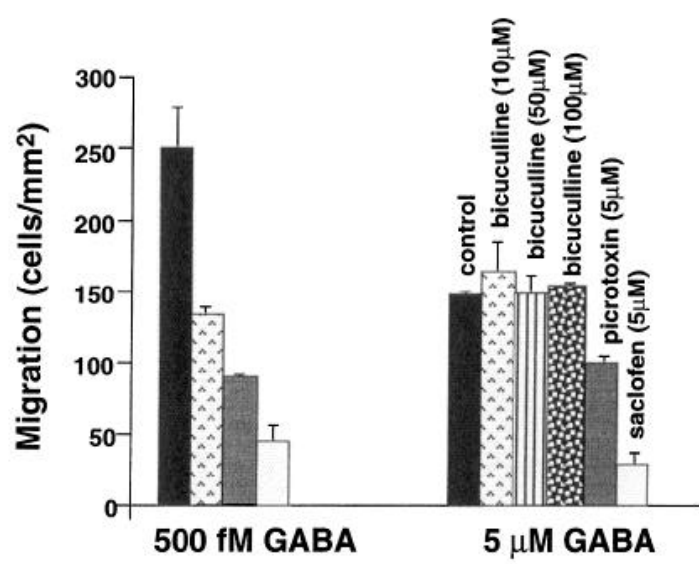

Figure 5. Antagonists at $\mathrm{GABA}_{\mathrm{A}}$ and $\mathrm{GABA}_{\mathrm{B}}$ receptors alter $\mathrm{GABA}$ induced migration. Chemotaxis of E18 cells to $500 \mathrm{fm}$ GABA is partially blocked by the $\mathrm{GABA}_{\mathrm{A}}$ antagonists bicuculline and picrotoxin and by the $\mathrm{GABA}_{\mathrm{B}}$ antagonist 2-hydroxysaclofen. Chemokinesis to $5 \mu \mathrm{M}$ GABA is partially blocked by $5 \mu \mathrm{M}$ picrotoxin or saclofen but not at all by $10-100$ $\mu \mathrm{M}$ bicuculline. See figure for drugs and designations. 

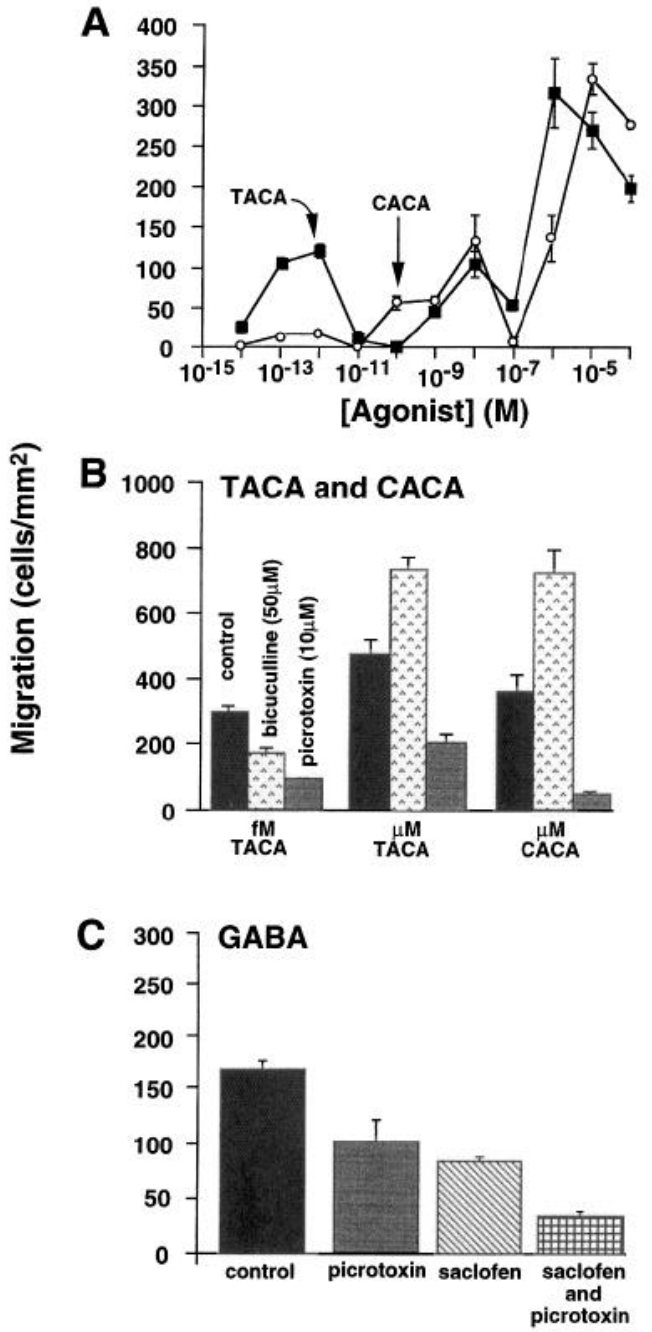

Figure 6. The $\mathrm{GABA}_{\mathrm{C}}$ agonists TACA and CACA mimic the chemokinetic effects of micromolar GABA. A, Micromolar levels of CACA (open circles) $\left(10^{-6}\right.$ to $\left.10^{-4} \mathrm{M}\right)$ or TACA (filled squares) $\left(10^{-6}\right.$ to $\left.10^{-4} \mathrm{M}\right)$ stimulate significant motility responses at E17. Cells demonstrate the greatest response to micromolar concentrations, as well as detectable movement at $10^{-8} \mathrm{M}$. Only TACA stimulates significant responses at lower $\left(10^{-13}\right.$ to $\left.10^{-12} \mathrm{M}\right)$ concentrations. $B$, Micromolar CACA- and TACAinduced responses in E17 cells are not blocked (but enhanced) by $50 \mu \mathrm{M}$ bicuculline and are inhibited by $10 \mu \mathrm{M}$ picrotoxin, consistent with $\mathrm{GABA}_{\mathrm{C}^{-}}$ type receptor involvement. Responses to femtomolar TACA are partially blocked by these antagonists. $C$, Motility induced by $5 \mu \mathrm{M}$ GABA is partially blocked by saclofen $(5 \mu \mathrm{M})$ and picrotoxin $(10 \mu \mathrm{M})$ alone and completely blocked in the presence of both (saclofen and picrotoxin; $5 \mu \mathrm{M}$ each).

Chemotaxis to femtomolar GABA was mimicked by the $\mathrm{GABA}_{\mathrm{A}}$ agonist muscimol and was partially inhibited by bicuculline, an antagonist at $\mathrm{GABA}_{\mathrm{A}}$ receptors. Cells in the ventricular zone of the cortex express transcripts encoding three $\mathrm{GABA}_{\mathrm{A}}$ receptor subunit proteins ( $\alpha 4, \beta 1$, and $\gamma 1)$ (Ma and Barker, 1995) during the embryonic period studied for migration (E15-E21). Although the pharmacology of femtomolar GABA-induced migration suggests the involvement of $\mathrm{GABA}_{\mathrm{A}}$ subunit proteins, femtomolar GABA has not been reported to activate $\mathrm{Cl}^{-}$channels. Instead, when $\mathrm{GABA}_{\mathrm{A}}$ receptor subunit proteins form functional $\mathrm{Cl}^{-}$ion channels, submicromolar to micromolar GABA is consistently required for activation. Therefore, the relationship, if

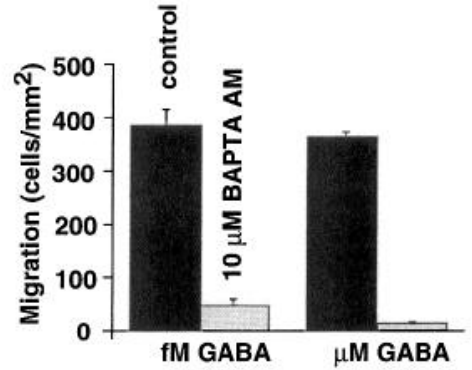

Figure 7. BAPTA blocks GABA-induced chemotropic effects. Migration of E17 cells to $500 \mathrm{fM}$ or $5 \mu \mathrm{M}$ GABA is almost entirely blocked in the presence of $10 \mu \mathrm{M}$ BAPTA-AM. Black bars, control (attractant only); shaded bars, GABA with $10 \mu \mathrm{M}$ BAPTA-AM.

any, between these $\mathrm{GABA}_{\mathrm{A}}$ receptor subunit proteins and GABA-induced chemotaxis and $\mathrm{Ca}_{\mathrm{c}}^{2+}$ signals remains to be elucidated.

$\mathrm{GABA}_{\mathrm{B}}$-like receptors also seem to mediate neuronal movement. R-baclofen, a $\mathrm{GABA}_{\mathrm{B}}$ receptor agonist, mimicked the effects of GABA at both femto- and micromolar concentrations, and these effects were substantially inhibited by 2hydroxysaclofen, a specific antagonist of $\mathrm{GABA}_{\mathrm{B}}$ receptors. These results imply that $\mathrm{GABA}_{\mathrm{B}}$-like receptors mediate both chemotactic and chemokinetic signals of GABA in subsets of cortical neurons during the final week of gestation. Binding studies on neonatal rat brain sections provide evidence that $\mathrm{GABA}_{\mathrm{B}}$ receptors are expressed in vivo within the developing neocortex. By birth (the earliest age examined), $\mathrm{GABA}_{\mathrm{B}}$ receptors seem to be widely distributed throughout the inner and middle two-thirds of the cortex, regions consistent with the location of migratory cells (Turgeon and Albin, 1994).

Functional $\mathrm{GABA}_{\mathrm{C}}$-like receptors may also mediate neuron motility. Micromolar GABA-induced chemokinesis was entirely resistant to bicuculline but was partially sensitive to picrotoxin. The $\mathrm{GABA}_{\mathrm{C}}$ ligands TACA and CACA stimulated random movement in subpopulations of embryonic cortical neurons that was picrotoxin-sensitive. Thus, the pharmacology of GABA-induced chemokinesis in a subpopulation of cells resembles that of recently described, picrotoxin-sensitive, bicuculline-resistant $\mathrm{GABA}_{\mathrm{C}}$ receptors (Cutting et al., 1991; Shimada et al., 1992; Qian and Dowling, 1993). The transient expression of picrotoxinsensitive, bicuculline-resistant $\mathrm{GABA}_{\mathrm{C}}$-like receptors in the postnatal hippocampus has been reported recently (Strata and Cherubini, 1994). A similar transient expression of $\mathrm{GABA}_{C}$-like receptors, which mediate motility in neurons, may occur within the developing embryonic neocortex.

Although micromolar muscimol mimicked the chemokinetic effects of micromolar GABA, thus implying the involvement of $\mathrm{GABA}_{\mathrm{A}}$-like receptors, micromolar GABA-induced motility was entirely resistant to bicuculline, a well established antagonist of $\mathrm{GABA}_{\mathrm{A}} / \mathrm{Cl}^{-}$channels in adults. Thus, it is unlikely that $\mathrm{GABA}_{\mathrm{A}}$ receptors mediate the chemokinetic effects of micromolar GABA. Instead, the TACA- and CACA-activated $\mathrm{GABA}_{\mathrm{C}}$-like receptors involved in chemokinesis may be muscimol-sensitive. Furthermore, TACA- and CACA-induced motility was significantly enhanced by bicuculline. These GABA analogs may also activate the bicuculline-sensitive $\mathrm{Cl}^{-}$channels. Thus, the latter may serve to modulate the extent of random motility induced by $\mathrm{GABA}_{\mathrm{B}}$ and $\mathrm{GABA}_{\mathrm{C}}$-like receptors.

Optical recordings of Fura-2-labeled cells demonstrated that mi- 


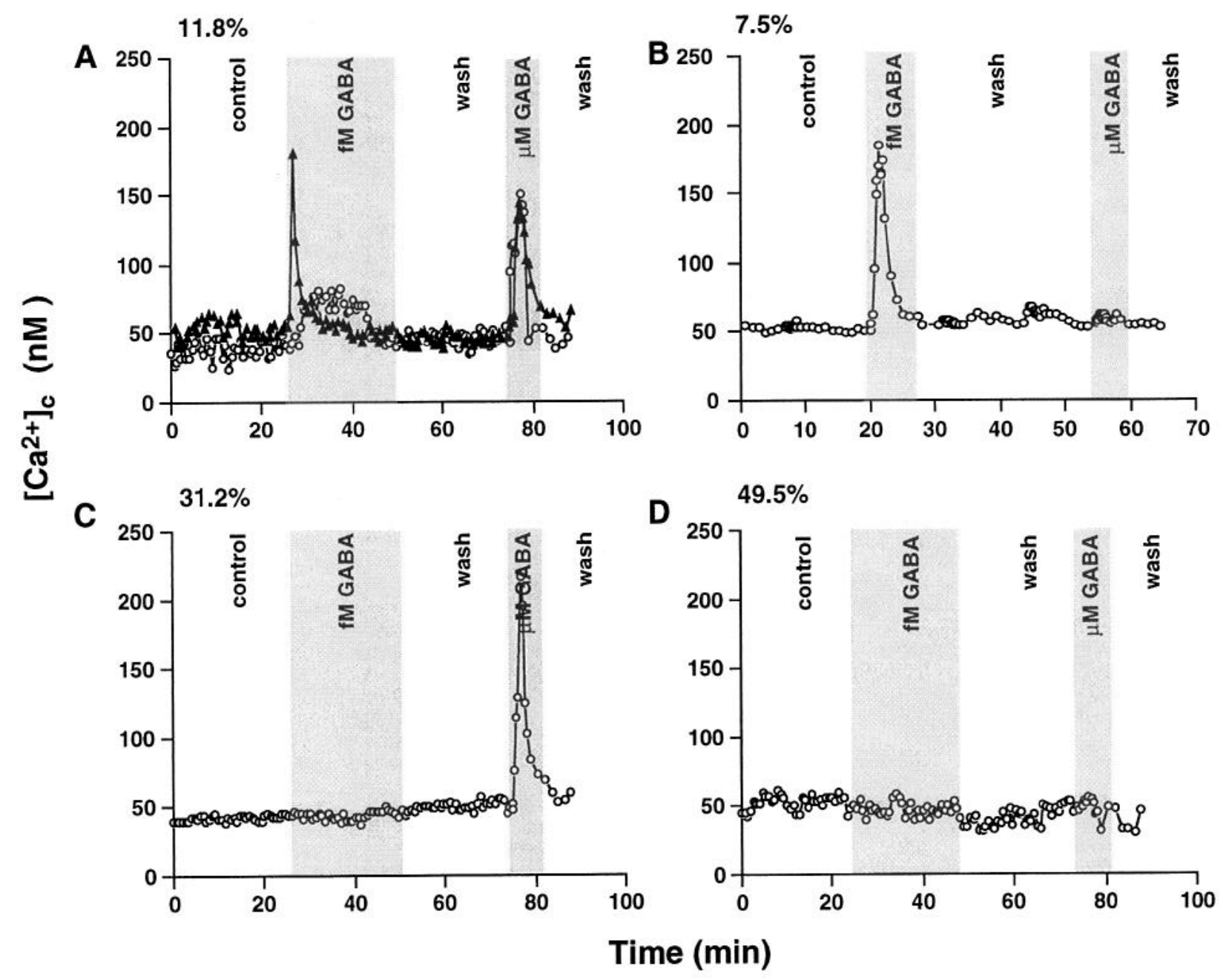

Figure 8. Femtomolar and micromolar GABA stimulates increases in cytoplasmic $\mathrm{Ca}^{2+}$. Digital videomicroscopic recordings of acutely adherent E17 cells loaded with $\mathrm{Ca}^{2+}$ indicator dye (Fura-2) were made to reveal and compare $\mathrm{Ca}_{\mathrm{c}}^{2+}$ responses at chemoattractant concentrations. Cells were sequentially exposed to $500 \mathrm{fm}$ then $10 \mu \mathrm{M}$ GABA. Two cells in a field $(A)$ respond to both femtomolar and micromolar GABA. $(A)$ One cell $(O)$ demonstrates a delayed, twofold rise in $\mathrm{Ca}_{\mathrm{c}}^{2+}$ during exposure to femtomolar GABA that relaxes during exposure. Another cell in the field $(\mathbf{\Lambda})$ exhibits a more rapid, transient increase in $\mathrm{Ca}_{\mathrm{c}}^{2+}$ during exposure to femtomolar GABA. In both cells, $\mathrm{Ca}_{\mathrm{c}}^{2+}$ recovers to baseline levels during the subsequent wash; $10 \mu \mathrm{M}$ GABA triggers transient $\mathrm{Ca}_{\mathrm{c}}^{2+}$ responses in both cells. $B$, The cell responds only to femtomolar $\mathrm{GABA}$ and exhibits a delayed, transient increase in $\mathrm{Ca}_{\mathrm{c}}^{2+}$ during exposure. $C$, The cell responds transiently to micromolar GABA only, whereas the cell in $D$ fails to respond to either concentration of GABA. In five separate trials, 165 cells were examined. The cells depicted in $A, C$, and $D$ were recorded in a single experiment; the cell in $B$ was recorded in a separate trial. $A, 7.8 \%$ of the starting population exhibited the pattern of response to femtomolar GABA, which is depicted by cell $O ; 4.0 \%$ of the starting population exhibited the pattern of response to femtomolar GABA, which is depicted by cell $\mathbf{\Lambda} . B, 7.5 \%$ of the cells only responded to femtomolar GABA; $31.2 \%$ of the cells responded to micromolar GABA only $(C)$; and $49.5 \%$ of the cells were unresponsive to GABA $(D)$. Unshaded lanes, Perfusion with standard bath solution; shaded lanes, perfusion with GABA.

cromolar concentrations of baclofen and CACA elevate $\mathrm{Ca}_{\mathrm{c}}^{2+}$, suggesting that chemokinesis is mediated via both $\mathrm{GABA}_{\mathrm{B}}$ and $\mathrm{GABA}_{\mathrm{C}}$ receptors. These receptors seem to be segregated among discrete subsets of cells. In the $\mathrm{Ca}^{2+}$-imaging experiments, one subset responded to baclofen only, a second subset responded to CACA only, and a third small subset responded to both baclofen and CACA.

The GABAmimetics used in our studies are traditionally used to discriminate among classically described GABA receptors in mature neurons and glia. Experiments to identify the receptor proteins and associated signal transduction pathways of the migratory cells will help to further characterize the embryonic receptors that mediate the motility signals of GABA.

In summary, neurons acutely isolated from the developing rodent cortex migrate in vitro to wide-ranging although discrete concentrations of GABA. Pharmacological antagonism of these effects strongly suggests that specific receptors mediate motility. Embryonic cortical neurons express GABA receptors, which trigger $\mathrm{Ca}^{2+}$ transients, and GABA-mediated motility is $\mathrm{Ca}_{\mathrm{c}}^{2+}$-dependent, suggesting that $\mathrm{Ca}^{2+}$ is an important signaling mechanism associated with GABAstimulated locomotion. The presence of GABA in the developing cortex, coupled with the observation that embryonic neurons express GABA receptors during developmental stages in which migration occurs, suggests that in vivo, GABA functions as a chemoattractant and that chemotropic effects of the molecule help determine the ultimate position of neurons in the cerebral cortex. The transient, concomitant expression of GABA and its receptors has also been demonstrated during similar stages of telencephalic development in 
$12.6 \%$
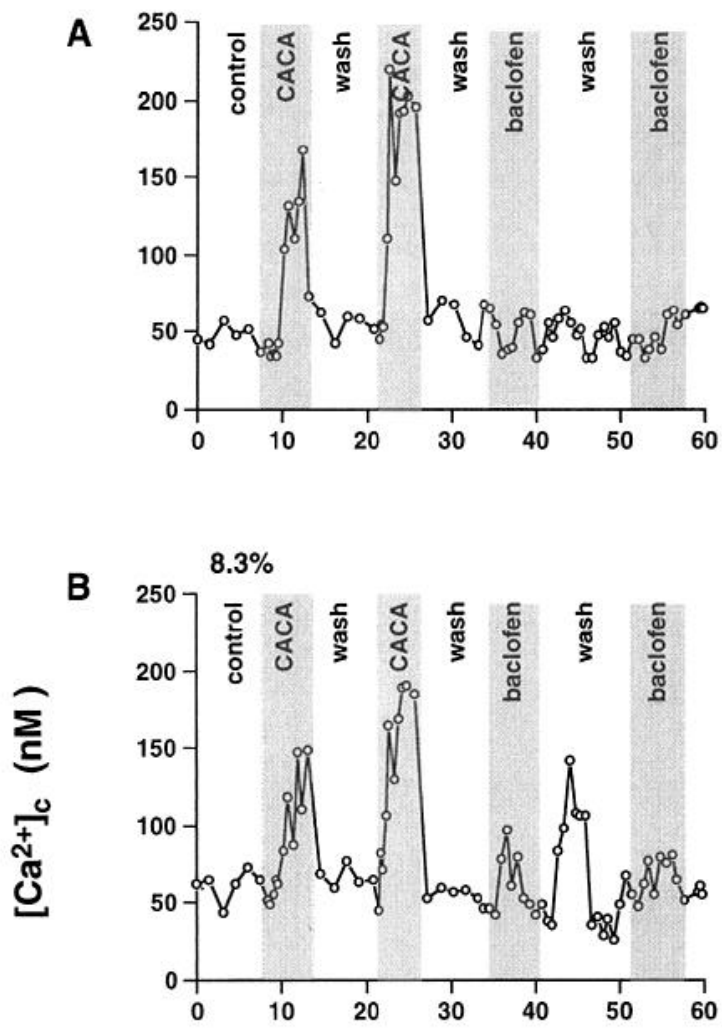

$9.3 \%$

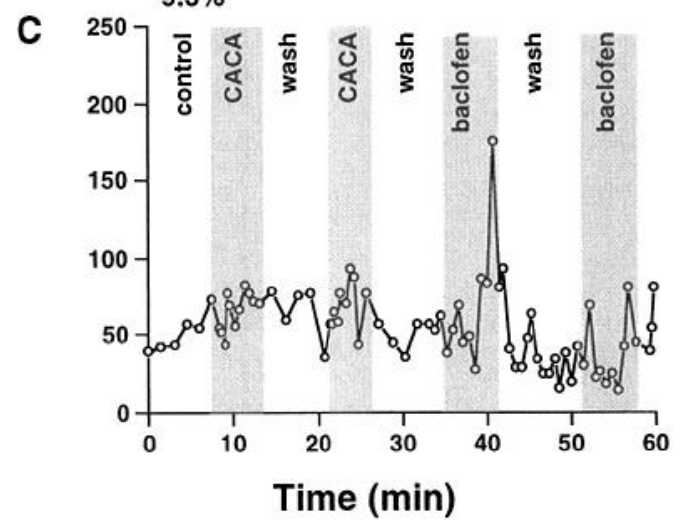

Figure 9. Micromolar CACA and baclofen increase cytoplasmic $\mathrm{Ca}^{2+}$. Digital videomicroscopic recordings of acutely adherent E17 cells exposed to $10 \mu \mathrm{M} \mathrm{CACA}$ then $10 \mu \mathrm{M}$ baclofen reveals the cellular distributions of $\mathrm{Ca}_{c}^{2+}$ responses to the two ligands. One cell $(A)$ responds, with a several minute delay, to CACA only. The rise in $\mathrm{Ca}_{c}^{2+}$ is maintained during exposure but recovers quickly during the subsequent wash. $B$, The cell responds with variable delays to both $C A C A$ and baclofen, with the latter relaxing to baseline levels during exposure, followed by a spontaneous elevation in $\mathrm{Ca}_{\mathrm{c}}^{2+}$ during the subsequent wash. $C$, The cell responds with a several minute delay only to baclofen, and the response relaxes within minutes during washout. Baclofen does not trigger another response when applied 10 min later. $A, 12.6 \%$ of the cells responded to CACA only; $B$, $8.3 \%$ responded to both baclofen and $\mathrm{CACA} ; C, 9.3 \%$ responded to baclofen only. Unshaded lanes, Perfusion with standard bath solution; shaded lanes, perfusion with GABAmimetic.

primates (Meinecke and Rakic, 1992; Schwartz and Meinecke, 1992). Hence, GABA-modulated regulation of cell motility may be generalized across mammalian species.

\section{REFERENCES}

Armstrong RC, Harvath L, Dubois-Dalcq M (1990) Type 1 astrocytes and oligodendrocyte-type 2 astrocyte glial progenitors migrate toward distinct molecules. J Neurosci Res 27:400-407.

Austin CP, Cepko CL (1990) Cellular migration patterns in the developing mouse cerebral cortex. Development 110:713-732.

Bayer SA, Altman J, Russo RJ, Dai XF, Simmons JA (1991) Cell migration in the rat embryonic neocortex. J Comp Neurol 307:499-516.

Behar T, Schaffner A, Laing P, Hudson L, Komoly S, Barker J (1993) Many spinal cord cells transiently express low molecular weight forms of glutamic acid decarboxylase during embryonic development. Dev Brain Res 72:203-218.

Behar TN, Schaffner AE, Colton CA, Somogyi R, Olah Z, Lehel C, Barker JL (1994a) GABA-induced chemokinesis and NGF-induced chemotaxis of embryonic spinal cord neurons. J Neurosci 14:29-38.

Behar T, Ma W, Hudson L, Barker JL (1994b) Analysis of the anatomical distribution of GAD67 mRNA encoding truncated glutamic acid decarboxylase proteins in the embryonic rat brain. Dev Brain Res 77:77-87.

Bowery NG (1993) GABA B $_{B}$ receptor pharmacology. Annu Rev Pharmacol Toxicol 33:109-147.

Cobas A, Fairen A, Alvarez BG, Sanchez MP (1991) Prenatal development of the intrinsic neurons of the rat neocortex: a comparative study of the distribution of GABA-immunoreactive cells and the $\mathrm{GABA}_{\mathrm{A}}$ receptor. Neuroscience 40:375-397.

Cutting GR, Lu L, O'Hara BF, Kasch LM, Montrose RC, Donovan DM, Shimada S, Antonarakis SE, Guggino WB, Uhl GR, Kazazian HH (1991) Cloning of the $\gamma$-aminobutyric acid (GABA) rho 1 cDNA: a GABA receptor subunit highly expressed in the retina. Proc Natl Acad Sci USA 88:2673-2677.

Dillon SB, Verghese MW, Snyderman R (1988) Signal transduction in cells following binding of chemoattractants to membrane receptors. Virchows Arch B Cell Pathol 55:65-80.

Falk W, Goodwin RH, Leonard EJ (1980) A 48 well micro chemotaxis assembly for rapid and accurate measurement of leukocyte migration. J Immunol Methods 33:239-247.

Feigenspan A, Wassle H, Bormann J (1993) Pharmacology of GABA receptor $\mathrm{Cl}^{-}$channels in rat retinal bipolar cells. Nature 361:159-162.

Geiser T, Dewald B, Ehrengruber MU, Clark LI, Baggiolini M (1993) The interleukin-8-related chemotactic cytokines GRO $\alpha$, GRO $\beta$, and GRO $\gamma$ activate human neutrophil and basophil leukocytes. J Biol Chem 268:15419-15424.

Gordon-Weeks PR, Lockerbie RO, Pearce B (1984) Uptake and release of $\left[{ }^{3} \mathrm{H}\right] \mathrm{GABA}$ by growth cones isolated from neonatal rat forebrain. Neurosci Lett 52:205-210.

Grant MB, Khaw PT, Schultz GS, Adams JL, Shimizu RW (1992) Effects of epidermal growth factor, fibroblast growth factor, and transforming growth factor- $\beta$ on corneal cell chemotaxis. Invest Ophthalmol Vis Sci 33:3292-3301.

Harvath L, Falk W, Leonard EJ (1980) Rapid quantitation of neutrophil chemotaxis: use of a polyvinylpyrrolidone-free polycarbonate membrane in a multiwell assembly. J Immunol Methods 37:39-45.

Hendey B, Klee CB, Maxfield FR (1992) Inhibition of neutrophil chemokinesis on vitronectin by inhibitors of calcineurin. Science 258:296-298.

Higashiyama S, Abraham JA, Klagsbrun M (1993) Heparin-binding EGF-like growth factor stimulation of smooth muscle cell migration: dependence on interactions with cell surface heparan sulfate. J Cell Biol 122:933-940.

Hinrichsen RD (1993) Calcium and calmodulin in the control of cellular behavior and motility. Biochim Biophys Acta 1155:277-293.

Imamoto K, Karasawa N, Isomura G, Nagatsu I (1994) Cajal-Retzius neurons identified by GABA immunohistochemistry in layer I of the rat cerebral cortex. Neurosci Res 20:101-105.

Jackel C, Krenz WD, Nagy F (1994) A receptor with GABA -like pharmacology in invertebrate neurones in culture. NeuroReport 5:1097-1101.

Jacobson M (1991) Developmental neurobiology. New York: Plenum.

Kerr DIB, Ong J (1992) GABA agonists and antagonists. Med Res Rev 12:593-636.

Lauder JM, Han VKM, Henderson P, Verdoorn T, Towle AC (1986) Prenatal ontogeny of the GABAergic system in the rat brain: an immunocytochemical study. Neuroscience 19:465-493.

Lukasiewicz PD, Maple BR, Werblin FS (1994) A novel GABA receptor on bipolar cell terminals in the tiger salamander retina. J Neurosci $14: 1202-1212$. 
Ma W, Barker JL (1995) Complementary expressions of transcripts encoding $\mathrm{GAD}_{67}$ and $\mathrm{GABA}_{\mathrm{A}}$ receptor $\alpha 4, \beta 1$ and $\gamma 1$ subunits in the proliferative zone of the embryonic rat central nervous system. J Neurosci 15:2547-2560.

Meinecke DL, Rakic P (1992) Expression of GABA and GABA receptors by neurons of the subplate zone in developing primate occipital cortex: evidence for transient local circuits. J Comp Neurol 317:91-101.

O'Rourke NA, Dailey ME, Smith SJ, McConnell SK (1992) Diverse migratory pathways in the developing cerebral cortex. Science 258:299-302.

O'Rourke NA, Sullivan DP, Kaznowski CE, Jacobs AA, McConnell SK (1995) Tangential migration of neurons in the developing cerebral cortex. Development 121:2165-2176.

Qian H, Dowling JE (1993) Novel GABA responses from rod-driven retinal horizontal cells. Nature 361:162-164.

Rakic $\mathbf{P}$ (1988) Specification of cerebral cortical areas. Science 241:170-176.

Reinisch N, Kirchmair R, Kahler CM, IIogue-Angeletti R, FischerColbrie R, Winkler H, Wiedermann CJ (1993) Attraction of human monocytes by the neuropeptide secretoneurin. FEBS Lett 334:41-44.

Rot A, Krieger M, Brunner T, Bischoff SC, Schall TJ, Dahinden CA (1992) RANTES and macrophage inflammatory protein $1 \alpha$ induce the migration and activation of normal human eosinophil granulocytes. J Exp Med 176:1489-1495.

Schaffner A, Behar T, Nadi S, Barker JL (1993) Quantitative analysis of transient GABA expression in embryonic and early postnatal rat spinal cord neurons. Dev Brain Res 72:265-276.

Schwartz ML, Meinecke DL (1992) Early expression of GABAcontaining neurons in the prefrontal and visual cortices of rhesus monkeys. Cereb Cortex 2:16-37.
Shimada S, Cutting G, Uhl GR (1992) $\gamma$-Aminobutyric acid A or C receptor? $\gamma$-Aminobutyric acid rho 1 receptor RNA induces bicuculline-, barbiturate-, and benzodiazepine-insensitive $\gamma$-aminobutyric acid responses in Xenopus uocytes. Mol Pharmacol 41:683-687.

Shure D, Senior RM, Griffin GL, Deuel TF (1992) PDGF AA homodimers are potent chemoattractants for fibroblasts and neutrophils, and for monocytes activated by lymphocyte cytokines. Biochem Biophys Res Commun 186:1510-1514.

Sivilotti I, Nistri A (1991) GABA receptor mechanisms in the central nervous system. Prog Neurobiol 36:35-92.

Stracke ML, Engel JD, Wilson LW, Rechler MM, Liotta LA, Schiffmann E (1989) The type I insulin-like growth factor receptor is a motility receptor in human melanoma cells. J Biol Chem 264: $21544-21549$.

Strata F, Cherubini E (1994) Transient expression of a novel type of GABA response in rat CA3 hippocampal neurons during development. J Physiol (Lond) 480:493-503.

Taylor J, Docherty M, Gordon-Weeks PR (1990) GABAergic growth cones: release of endogenous $\gamma$-aminobutyric acid precedes the expression of synaptic vesicle antigens. J Neurochem 54:1689-1700.

Turgeon S, Albin R (1994) GABA $\mathrm{G}_{B}$ binding in rat brain. Neuroscience 62:601-613.

Van Eden CG, Mrzljak L, Voorn P, Uylings HBM (1989) Prenatal development of GABA-ergic neurons in the neocortex of the rat. J Comp Neurol 289:213-227.

Walsh C, Cepko CL (1992) Widespread dispersion of neuronal clones across functional regions of the cerebral cortex. Science 255:373.

Yao J, Gilbert D, Colton C (1990) Chemotaxis of cultured CNS microglia. J Neurosci Res 27:36-42. 